\title{
Creative Work Environment as a Factor of Innovations in Transport Companies in the Republic of Serbia
}

\author{
MILICA LJ. ŽAREVAC BOŠKOVIĆ, Academy of Professional Studies Šumadija \\ Department in Kragujevac, Kragujevac \\ DRAGAN D. RAJKOVIĆ, Academy of Professional Studies \\ Professional paper \\ $U D C:$ 656.1/.5:005.96 \\ 656.11.5:658
}

Šumadija, Department in Kragujevac, Kragujevac

MARIJA S. LAKIĆEVIĆ, University of Kragujevac,

Faculty of Hotel Management and Tourism, Vrnjačka Banja
DOI: 10.5937/tehnika2102206Z

The variability of environment, growing number of external factors of companies' businesses, inaccessible key organizational resources, inability of management to understand or predict changes and trends in the general organizational environment due to growing uncertainties are just some of the characteristics of the modern business world, especially the transport sector as one of the most complex segment of each country's economic system. The paper analyzes the level of development of creative work environment in transport companies in the Republic of Serbia in order to formulate possible, and possibly necessary, guidelines for greater encouragement of employees' creativity, as organizational innovations today represent, it seems, the only potential solution for overcoming all obstacles and surviving in such a complex market.

Key words: innovations, creative work environment, traffic

\section{INTRODUCTION}

Permanently encouraging employees to be creative and defining new ideas whose realization often results in organizational innovations that change the (business) world, probably gives every company today the best chance to create a sustainable competitive advantage.

Since Van de Ven defines organizational creation as a essential element of the innovation [1], Burcu and Ceyda explained process of innovation as a complex category which pertains to various organizational segments and activities [2]. Generally speeking, the term "organizational innovation" is the generation or taking over of an thought or performance new to the organization [3], [4] and [5].

Hulpke [6] explained that creativity arises at the personal, but innovation arises at the departmental le vel, so there is a need that before departmental innovation, there must be personal creativity.

Author's address: Milica Žarevac Bošković, Academy of Professional Studies Šumadija, Department in Kragujevac, Kragujevac, Kosovska 8

e-mail: zarevac.milica@gmail.com

Paper received: 28.11.2020.

Paper accepted. 30.12.2020.
One one side, there are many studies that show approach to exterior assets explains the level of innovativeness in organization [7], but less is known about the importance of creativity for innovation. Teece [8] distinguishes two kinds of innovation. The first one, an autonomous innovation, does not demand colossal changes, for example, the introduction of power steering which did not require any adjustments to the design of cars. On the other hand, systematic innovations demands whole redesign, for example, the move to front-wheel drive switched design of many cars. Also, one recent study by Anastasios, Mitchell, Konstantinos and Ferenc [9] focuses on the active role of the public sector and the demands for establishing an effective solution to help understand the revolution in transport innovation. Whatmore, for many years in the 20th century General Motors was at the vary top of the Fortune 500 list, but in 2009 something went wrong and the company declared bankruptcy.

Whole public, managers and researchers were sure about having the need of innovation and creativity in this case and, suddenly, everyone rememberd about the words by Jacob Goldman qouted in one article [10]: ,If there is any industrial area ... where an important idea is absolutely essential for survival, it is the automobile industry..." 


\section{METHODOLOGY}

The research was conducted in September 2020 and all respondents, at the time of the research, were employed in six transport companies in the Republic of Serbia, which were randomly marked with the letters A, B, C, D, E and F. According to the level of generalization of a conclusion, this is an operational research because a relatively small sample of 60 respondents (ten respondents per one company) was used.

One type of method was used, explicit, and it was empirical-experimental because the research involved collecting data in the field, and close-ended questions were used as a research technique. Also, the survey was completely anonymous which contributed to greater honesty and objectivity of the respondents in giving answers, and this, in the final instance, certainly increased the importance of the research and the quality of the obtained results.

Using a creative work environment model, according to T.M. Amabile et al. [11], six survey questions were formulated which addressed six components such as: Challenging job, organization support, supervisor support, working group support, freedom and the absence of barriers within organization. The respondents were asked to simply choose between the answers „yes“ and „no“, which confirmed, or denied the presence of a certain component in their work environment. The aim of the survey was to determine the fulfilment of possible conditions for organizational innovations in the surveyed transport companies through the identification of key dimensions of creative work environment.

\section{RESULTS AND DISCUSSION}

Innovation is an essential condition for economic progress and a key element in the competitive struggle of companies and nation states [12]. However, the starting point of innovation management is actually the management of innovation sources. Having in mind the fact that a small number of companies today can boast of great and ingenious minds as sources of creativity of new and revolutionary ideas, management must focus on creating such work environment that would encourage and motivate employees to think more creatively.

One of the characteristics of creative work environment would be a challenging job that produces a peculiar psychological state [13] creating a sense of satisfaction in the employee while performing a certain task. Creative work environment also involves three types of support [14]: support from the organization, supervisor and working group. Finally, work environment that should encourage creativity must be characterized by the existence of freedom of employees in their work

The authors of this paper rank the level of development of creative work environment as follows: in companies with a total of $0-34 \%, 35-70 \%$, or $71-100 \%$ of affirmative answers, a low, moderate, or high level of development is determined, respectively. While the absolute values are presented in Table 1, relative values are shown in Table 2. Additionally, the values in Table 2, for better insight, are presented in Diagram 1.

In company A respondents answered 51 questions in the affirmative, i.e. only 9 questions in the negative (Table 1).

Table 1. Results of testing the level of development of a creative work environment in transport companies in the Republic of Serbia (absolute values)

\begin{tabular}{|c|c|c|c|c|c|c|c|c|c|}
\hline Components & Answers & A & B & $\mathrm{C}$ & $\mathrm{D}$ & $\mathrm{E}$ & $\mathrm{F}$ & \multicolumn{2}{|c|}{$\begin{array}{l}\text { Total by components and type } \\
\text { of response }\end{array}$} \\
\hline \multirow{2}{*}{ Challenging job } & yes & 8 & 6 & 2 & 1 & 5 & 7 & \multicolumn{2}{|l|}{29} \\
\hline & no & 2 & 4 & 8 & 9 & 5 & 3 & \multicolumn{2}{|l|}{31} \\
\hline \multirow{2}{*}{ Organization support } & yes & 8 & 7 & 0 & 2 & 5 & 10 & \multicolumn{2}{|l|}{32} \\
\hline & no & 2 & 3 & 10 & 8 & 5 & 0 & \multicolumn{2}{|l|}{28} \\
\hline \multirow{2}{*}{ Supervisor support } & yes & 10 & 7 & 0 & 2 & 3 & 10 & \multicolumn{2}{|l|}{32} \\
\hline & no & 0 & 3 & 10 & 8 & 7 & 0 & \multicolumn{2}{|l|}{28} \\
\hline \multirow{2}{*}{ Working group support } & yes & 8 & 6 & 3 & 0 & 4 & 9 & \multicolumn{2}{|l|}{30} \\
\hline & no & 2 & 4 & 7 & 10 & 6 & 1 & \multicolumn{2}{|l|}{30} \\
\hline \multirow{2}{*}{ Freedom } & yes & 10 & 5 & 3 & 1 & 4 & 7 & \multicolumn{2}{|l|}{30} \\
\hline & no & 0 & 5 & 7 & 9 & 6 & 3 & \multicolumn{2}{|l|}{30} \\
\hline \multirow{2}{*}{$\begin{array}{l}\text { The absence of barriers } \\
\text { within the company }\end{array}$} & yes & 7 & 7 & 0 & 1 & 5 & 8 & \multicolumn{2}{|l|}{28} \\
\hline & no & 3 & 2 & 10 & 9 & 5 & 2 & \multicolumn{2}{|l|}{32} \\
\hline \multirow{2}{*}{$\begin{array}{l}\text { Total by subject and type of } \\
\text { response }\end{array}$} & yes & 51 & 38 & 8 & 7 & 26 & 51 & 181 & \multirow{2}{*}{360} \\
\hline & no & 9 & 22 & 52 & 53 & 34 & 9 & 179 & \\
\hline
\end{tabular}

Source: Authors of the paper 
The same result was found in company F. Special emphasis should be placed on the answers in company A related to the identification of the components such as supervisor support and freedom where all ten respondents answered in the affirmative. Also, in company $\mathrm{F}$ all ten affirmative answers are related to the components of organization and supervisor support. The largest number of negative answers, i.e. 3, in company A, refer to the absence of barriers within the company, while the same result was recorded in company $\mathrm{F}$ in the components challenging job and freedom. As high percentage of affirmative answers was found in companies A and F (Table 2), i.e. 85\%, which corresponds to values within the range between 71-100 \% of affirmative answers, it can be concluded that both companies have a high level of creative work environment, which greatly encourages creativity in employees and creates favorable conditions for organizational innovations.

In company $\mathrm{E}$, out of a total of 60 answers, 34 were negative, i.e. only 26 were affirmative (Table 1). Additionally, according to Table 2, as there were 56.67 $\%$ of negative, i.e. $43.33 \%$ of affirmative answers, which corresponds to values within the range between $35-70 \%$ of affirmative answers, company $\mathrm{E}$ is classified among those with a moderate level of development of creative environment. A somewhat more favorable situation was found in company B, which, like company $\mathrm{E}$, has an intermediate level of development of creative environment. Namely, out of a total of 60 answers, 38 were affirmative, i.e. 22 were negative (Table 1). When it comes to relative values, $63.33 \%$ of affirmative, i.e. $36.67 \%$ of negative answers were established (Table 2).

Table 2. Total relative values by subject and type of response (in \%)

\begin{tabular}{|l|l|l|l|l|l|l|l|l|l|}
\hline \multirow{2}{*}{$\begin{array}{l}\text { Total by } \\
\text { subject and } \\
\text { type of } \\
\text { response }\end{array}$} & Answers & A & B & C & D & E & F & \multicolumn{2}{|c|}{ Total by type of response } \\
\cline { 2 - 10 } & yes & 85 & 63.33 & 13.33 & 11.66 & 43.33 & 85 & 50.28 & 100 \\
\hline
\end{tabular}

Source: Authors of the paper

The most unfavorable situation was found in companies $\mathrm{C}$ and $\mathrm{D}$, since the number of negative answers was 52, i.e. $86.67 \%$, and 53, i.e. $88.34 \%$, and the number of affirmative answers was only 8, i.e. $13.33 \%$, and 7, i.e. $11.66 \%$, respectively (Table 1 and Table 2). Special emphasis should be placed on the answers in company $\mathrm{C}$ which are related to absolute non-recognition of components such as organization and supervisor support, as well as the absence of barriers within the company, where all ten respondents answered in the negative. The same situation is seen in company $\mathrm{D}$, in relation to the component working group support (Table 1). As the obtained values (13.33 $\%$ in company $\mathrm{C}$ and $11.66 \%$ in company $\mathrm{D})$ are within the range between $0-34 \%$ of affirmative answers, it is concluded that both companies have a low level of development of creative work environment which discourages creative expression of employees and creates unfavorable conditions for organizational innovations.

Diagram 1. Total number of affirmative answers by subject (in \%)

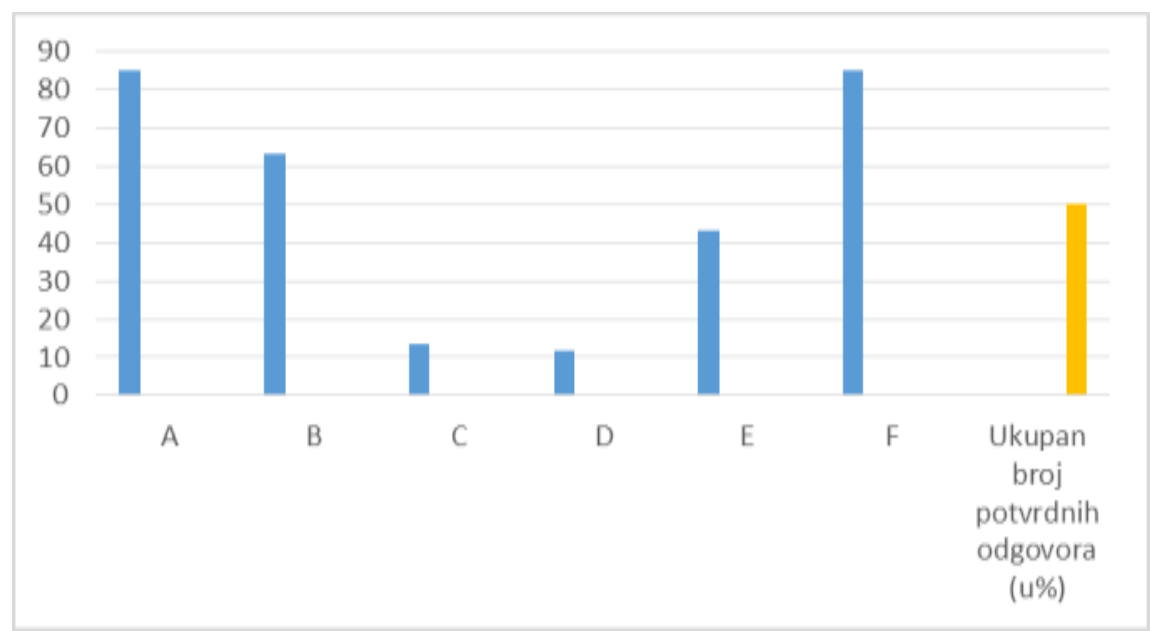

Source: Authors of the paper

When it comes to total values, out of a total of 360 answers received, 181 are affirmative, i.e. $50.28 \%$, and 179 are negative, i.e. $49.72 \%$ (Table 1 and Table 2).
In addition, relative values of affirmative answers by subject are presented in Diagram 1 where it is even more apparent what is the level of development of 
creative work environment in each of the examined subjects. Total relative value of affirmative answers was also singled out, i.e. $50.28 \%$, which corresponds to values within the range between $35-70 \%$, and which indicates probably relatively moderate level of development of creative work environment in the entire transport sector of the Republic of Serbia. Extending the examined sample might not lead to the same result, but it would certainly mean higher probability of the accuracy of the conclusion on this issue at the macro level.

Given that the results of the survey unequivocally indicate insufficient encouragement of employees to express their creativity, and, finally, the introduction of organizational innovations through the realization of new ideas, there is a need to indicate possible guidelines for more successful creation of creative work environment [15]: One of the ways to encourage creativity in employees is to give them challenging tasks in which the potential of workers and the expected requirements are in balance. Any imbalance between these elements causes dissatisfaction which destroys possible creativity. Support at all levels, of organization, supervisor and working group, is achieved when management encourages risk- taking, recognizes and rewards every form of creativity. Supervisors should set unambiguous goals, as well as have open conversation with employees. In working groups, it is vital to understand and accept the different statuses of group members, as well as to encourage a constructive way of resolving the conflict. Finally, the component of creative work environment related to freedom implies the absolute autonomy of each employee over the entire work process.

\section{CONCLUSION}

Apart from the growing competition and the already mentioned characteristics of the modern transport market as peculiar obstacles to companies on the way to achieve their competitive advantages, the current global COVID-19 epidemiological crisis, with indications of economic and social crisis, further complicates the survival of these businesses. Current global events are undoubtedly reminiscent of the not-sodistant past, when in a study of a crisis at a global level [16] was noticed that ,innovations in all areas, and especially in the development of new technologies contribute to global economic growth... However, man has never been so busy and accelerated, and at the same time insecure and worried about his existence, due to global financial crisis, which grows into an economic crisis, with the first signs of social crisis." Although crisis is most often explained as a state of mild and severe disturbances in economy, the word crisis comes from the Greek word krisis, which, in addition to being a disturbance and a difficult state, also means a turnover.

More than ever, transport companies have the need to create new ideas or at least adopt existing innovations as the only logical solution and a solid guarantee for overcoming the existing crisis and all market difficulties. Although the acceptance of existing innovations seems to be the easier way, in the Republic of Serbia the problem arises due to the incompatibility of certain exceptional innovations, such as the emergence of the so-called autonomous vehicles (driverless cars and delivery vehicles), with existing national regulations and standards (the 1968 Vienna Convention on Road Traffic still requires the driver behind the wheel). Moreover, as it was concluded in one recent study [17], development and application of new methods of analyzing and managing system quality and service should be based on basic requirements ISO 9001 standards, as well as EN listed standards, quality partnerships, and models evaluation. Other researcher [18] explained that while motivation theories help us come to appropriate solutions indicating potential ones problems concerning the behavior of employees in the workplace, in modern conditions, motivation is a great challenge for managers. It seems that due to the numerous limiting elements of external environment, of economic, legal and social character, as well as the insignificant probability that in every modern company today there are minds like Tesla, Edison or Dobrivoje Božić, who were themselves sources of revolutionary ideas and changes, the management of Serbian transport companies has no choice but to create a working environment with characteristics that would allow the employees' creativity to flourish, new ideas to be born, and innovations to ensure sustainable competitive advantage and survival of the organization.

\section{REFERENCES}

[1] Van de Ven A, Polley D, Garud S, Venkataraman S, The Innovation Journey. New York: Oxford University Press. 1999.

[2] Burcu K, Ceyda M, The Relationship between Knowledge Management and Innovation in Turkish Service and High-Tech Firms. International Journal of Business and Social Science. Vol. 4 No. 4. April, 2013.

[3] Daft R. L, A Dual-Core Model of Organizational Innovation. Academy of Management Review, 21, 193-210. 1978.

[4] Damanpour F, Evan W. M, Organizational Innovation and Performance: The Problem of Organizational Lag. Administrative Science Quarterly, 29, 392-402. 1984. 
[5] Damanpour F, Organizational Complexity and Innovation: Developing and Testing Multiple Contingency Models. Management Science, 42/5, 693-716. 1996.

[6] Hulpke J. F, No Individual Creativity, No Organizational Innovation, Journal of Innovation in Business and Economics, Vol. 03 No. 01, p. 1. June, 2019.

[7] Faems Dries, Bart Van Looy and Koenraad Debackere, Interorganizational Collaboration and Innovation: Toward a Portfolio Approach. Journal of Product Innovation Management, 22, 238-250. 2005.

[8] Teece D. J, Design issues for Innovative Firms: Bureaucracy, Incentives and Industrial Structure. In A. D. Chandler Jr, P. Hagstrom, and O. Solvell (eds.). The Dynamic Firm. Oxford. Oxford University Press. 1998.

[9] Anastasios T, Mitchell B, Konstantinos G, Ferenc P, TRIMIS: The European transport research and innovation policy tool supporting the transport innovation revolution. January, 2019.

[10]Business Week, The breakdown of US innovation. p. 58. February 16, 1975.
[11]Amabile R. Konti H, Kun Dž. Lejzenbi and Heron M, Assessing the Work Environment for Creativity, Academy of Management Journal, 39, 1154-1184. 1996.

[12]Mišić I, Inovacija u malim i srednjim preduzećima. Tehnika, 3. p. 469. 2012.

[13]Csikszentmihalyi. Flow: The Psychology of Optimal Experience. New York: Harper \& Row. 1990.

[14]Williams C, Principi Menadžmenta. Beograd. Data Status. ISBN: 978-86-7478-117-3. p. 121. 2010.

[15]Williams C, Principi Menadžmenta. Beograd. Data Status. ISBN: 978-86-7478-117-3. p. 120-121. 2010.

[16]Žarevac M, Financial Crisis and Current Trends on Global Market. LAP LAMBERT Academic Publishing. ISBN-10:3659616206, ISBN-13:9783659616204. 2014.

[17]Rajković D, Vasiljević S, Upravljanje kvalitetom usluge u javnom prevozu putnika. Tehnika, 3. p. 409. 2020.

[18]Jovanović G, Božilović S, Motivacija i politika upravljanja ljudskim resursima u organizaciji. Tehnika, 1. p. 117, 2017.

\section{REZIME}

\section{KREATIVNO RADNO OKRUŽENJE KAO FAKTOR INOVACIJA U TRANSPORTNIM KOMPANIJAMA U REPUBLICI SRBIJI}

Varijabilnost okruženja, sve veći broj spoljnih faktora poslovanja preduzeća, nepristupačni ključni organizacioni resursi, nesposobnost menadžmenta da razume ili predvidi promene $i$ trendove u opštem organizacionom okruženju usled rastućih neizvesnosti samo su neke od karakteristika savremenog poslovnog sveta, posebno transportni sektor kao jedan od najsloženijih segmenata ekonomskog sistema svake zemlje. U radu se analizira stepen razvoja kreativnog radnog okruženja u transportnim preduzećima u Republici Srbiji kako bi se formulisale moguće, a možda i neophodne smernice za veće podsticanje kreativnosti zaposlenih, jer organizacione inovacije danas predstavljaju, čini se, jedini potencijal rešenje za prevazilaženje svih prepreka i preživljavanje na tako složenom tržištu.

Ključne reči: inovacije, kreativno radno okruženje, saobraćaj 